University of Nebraska - Lincoln

DigitalCommons@University of Nebraska - Lincoln

\title{
Survey of Selected Pathogens and Blood Parameters of Northern Yellowstone Elk: Wolf Sanitation Effect Implications
}

\author{
Shannon M. Barber-Meyer \\ University of Minnesota, Saint Paul, sbarber-meyer@usgs.gov \\ P. J. White \\ National Park Service \\ L. David Mech \\ USGS Northern Prairie Wildlife Research Center, david_mech@usgs.gov
}

Follow this and additional works at: https://digitalcommons.unl.edu/usgsnpwrc

Part of the Other International and Area Studies Commons

\footnotetext{
Barber-Meyer, Shannon M.; White, P. J.; and Mech, L. David, "Survey of Selected Pathogens and Blood Parameters of Northern Yellowstone Elk: Wolf Sanitation Effect Implications" (2007). USGS Northern Prairie Wildlife Research Center. 73. https://digitalcommons.unl.edu/usgsnpwrc/73
}

This Article is brought to you for free and open access by the US Geological Survey at DigitalCommons@University of Nebraska - Lincoln. It has been accepted for inclusion in USGS Northern Prairie Wildlife Research Center by an authorized administrator of DigitalCommons@University of Nebraska - Lincoln. 


\title{
Survey of Selected Pathogens and Blood Parameters of Northern Yellowstone Elk: Wolf Sanitation Effect Implications
}

\author{
SHANNON M. BARBER-MEYER, ${ }^{1,4}$ P. J. WHITE ${ }^{2}$ AND L. DAVID MECH ${ }^{3}$ \\ ${ }^{1}$ Department of Fisheries, Wildlife, and Conservation Biology, University of Minnesota, 200 Hodson Hall, 1980 \\ Folwell Ave., Saint Paul, 55108, e-mail: shannonbarbermeyer@gmail.com \\ ${ }^{2}$ National Park Service, P.O. Box 168, Yellowstone National Park, WY 82190, USA, \\ e-mail:pj_white@nps.gov \\ ${ }^{3}$ U.S. Geological Survey, Northern Prairie Wildlife Research Center, 8711 - 37th St. SE, Jamestown, \\ ND 58401-7317, USA, e-mail: mechx002@umn.edu
}

\begin{abstract}
The restoration or conservation of predators could reduce seroprevalences of certain diseases in prey if predation selectively removes animals exhibiting clinical signs. We assessed disease seroprevalences and blood parameters of 115 adult female elk (Cervus elaphus) wintering on the northern range of Yellowstone National Park [YNP] during 20002005 and compared them to data collected prior to wolf (Canis lupus) restoration (WR) in 1995 and to two other herds in Montana to assess this prediction. Blood parameters were generally within two standard deviations of the means observed in other Montana herds (Gravelly-Snowcrest [GS] and Garnet Mountain [GM]), but Yellowstone elk had higher seroprevalences of parainfluenza-3 virus $(95 \%$ CI YNP $=61.1-78.6$, GS $=30.3-46.5)$ and bovine-virus-diarrhea virus type $1(95 \%$ CI $\mathrm{YNP}=15.9-31.9, \mathrm{GM}=0)$. In comparisons between pre-wolf restoration [pre-WR] (i.e., prior to 1995) seroprevalences with those postwolf restoration [post-WR] in Yellowstone, we found lower seroprevalences for some diseasecausing agents post-wolf restoration (e.g., bovine-virus-diarrhea virus type-1 [95\% CI pre-WR $=73.1-86.3$, post-WR $=15.9-31.9]$ and bovine-respiratory syncytial virus $[95 \%$ CI pre-WR $=$ 70.0-83.8, post-WR = 0]), but similar (e.g., Brucella abortus [95\% CI pre-WR $=0-4.45$, post-WR $=0-4.74]$ and epizootic hemorrhagic disease virus [95\% CI pre-WR $=0$, post-WR $=0]$ ) or higher for others (e.g., Anaplasma marginale [95\% CI pre-WR $=0$, post-WR $=18.5-38.7$ ] and Leptospira spp. [95\% CI pre-WR $=0.5-6.5$, post-WR $=9.5-23.5]$ ). Though we did not detect an overall strong predation effect through reduced disease seroprevalence using retrospective comparisons with sparse data, our reference values will facilitate future assessments of this issue.
\end{abstract}

\section{INTRODUCTION}

The high mountains and plateaus of Yellowstone National Park provide summer range for an estimated 10,000-25,000 elk (Cervus elaphus) from 8 herds. Most of these elk winter on separate ranges outside the park, owing to snowfalls that accumulate to more than $3 \mathrm{~m}$ on interior plateaus. These world-renowned herds provide significant visitor enjoyment and benefits to local economies (e.g., hunting). However, they also have been implicated in the transmission of diseases such as brucellosis (Brucella abortus), sarcoptic mange (scabies) and septicemic pasteurellosis to wildlife and domestic livestock in Idaho, Montana and Wyoming (Aguirre et al., 1995; Wolfe et al., 2002). These claims have led to proposals for eliminating diseases such as brucellosis from elk in the Greater Yellowstone Area by capture, test and slaughter (USDOI and USDA, 2000).

However, management proposals should consider the potential for selective predation to reduce disease prevalence in ungulate herds through natural means (i.e., a sanitation

\footnotetext{
${ }^{4}$ Corresponding author, present address: Mexican Wolf Reintroduction Project, PO Box 856, Alpine, AZ 85920, USA (phone: 928-339-4329, fax: 928-339-4218, e-mail: shannonbarbermeyer@gmail.com)
} 
effect). Yellowstone supports an intact large-predator complex, including black bears (Ursus americanus), coyotes (Canis latrans), grizzly bears (U. arctos) and cougars (Puma concolor); and wolves (C. lupus), which were reintroduced in 1995-96. Wolves increased rapidly and during 2000-2005 reached one of the highest densities recorded worldwide (Smith et al., 2003). Elk comprised 89\% of wolf kills during the winters of 1995-2005 (Smith et al., 2004) and elk in the northern part of the park decreased by approximately 50\% (White and Garrott, 2005). Wolves and hunters each took 7-8\% of adult cow elk annually (Evans et al., 2006). Bears and coyotes were also significant predators of neonatal elk during this period (Barber et al., 2005). If some diseases increase prey vulnerability, selective predation (Mech and Peterson, 2003) may reduce disease prevalence depending in part on the transmission dynamics of the disease (i.e., animals compromised by an infectious agent are not always the most important transmitters of the agent).

Some of the diseases summarized by Mech (1970) and (Mech et al., 1998) which apparently make prey more vulnerable to wolf predation include actinomycosis (a severe infection affecting jawbones), other skeletal diseases and disorders (e.g., arthritis), heavy hydatid-tapeworm (Echinococcus granulosus) cyst infestations, and poor condition evidenced by reduced marrow-fat suggesting some serious disease condition in the prey (unless there is a lack of adequate food). However, no previous studies have examined disease prevalence in prey pre- and post-wolf restoration. Yellowstone National Park presented this opportunity.

The National Research Council (NRC, 2002) recommended for Yellowstone that "Periodic surveillance for pathogens (including brucellosis) in wild ruminants in the northern range should be continued and a more thorough understanding of populationlevel threshold dynamics gained." Our first objective was to collect data to create reference values for selected pathogens and blood parameters in northern Yellowstone elk during 2000-2002 and 2005. Our second objective was to compare these seroprevalence data with: (1) data from Yellowstone elk prior to wolf restoration; and (2) data from two other elk herds in Montana to assess differences among areas and periods. We predicted the following changes in disease seroprevalences after wolf restoration: (1) decreased seroprevalence in certain diseases via wolves selectively removing elk with clinical manifestations of disease which increased their vulnerability to predation (Murie, 1944; Mech, 1966; Fuller, 1966: 36; see summary by Mech and Peterson, 2003:141); (2) decreased disease seroprevalence by a reduction in overall elk numbers which may reduce disease transmission if elk concentrations correspondingly change; and (3) potentially increased seroprevalence of some diseases depending on elk-herding behavior following wolf restoration (Mao, 2003) and, therefore, potentially increased disease transmission rate. Because elk in Yellowstone were already at high densities prior to wolf restoration (White and Garrott, 2005), we did not expect increased herding to be as important in disease dynamics compared to our first two predictions. Therefore, we hypothesized an overall decrease in disease seroprevalence following wolf restoration. Because the epidemiology (i.e., transmission dynamics, seasonal variabilities, clinical manifestation of disease) of many diseases in wild elk remains only partially understood (Depner et al., 1991; Aguirre et al., 1995; Frolich, 2000; NRC, 2002; Thorne et al., 2002) specific predictions with respect to particular diseases were not possible.

\section{METHODS}

Yellowstone National Park encompasses $8991 \mathrm{~km}^{2}$ of Wyoming, Montana and Idaho in the western United States $\left(44^{\circ} \mathrm{N}\right.$ latitude and $110^{\circ} \mathrm{W}$ longitude). Our study area included the winter range of northern Yellowstone elk, which consisted of $1520 \mathrm{~km}^{2}$ of foothills and 
valley bottoms along the Gardiner, Lamar and Yellowstone rivers. Nearly $1000 \mathrm{~km}^{2}$ of this area was within Yellowstone National Park and the remainder was on Gallatin National Forest, state and privately owned lands (Lemke et al., 1998). Annual counts of elk that wintered on the northern range during 2000-05 ranged between 8335-14,539 (White and Garrott, 2005). Descriptions of the climate, topography, vegetation and diverse predatorprey complex of this range during our study were provided in White and Garrott (2005) and the references cited therein.

We captured 115 adult female elk ( $\geq 1$-y old) using net-guns from helicopters during either Feb. or Mar. of 2000-02 and 2005 as described by Cook et al. (2004). Helicopter chases of elk generally lasted less than $1 \mathrm{~min}$. Animals were handled in compliance with the requirements of the Institutional Animal Care and Use Committee for the University of Minnesota and guidelines recommended by the American Society of Mammalogists (Animal Care and Use Committee, 1998). Biologists drew approximately $50 \mathrm{ml}$ of blood $(<5 \mathrm{~min}$ after netting the elk) by puncture of the jugular vein using 16 or 18 gauge $1 \frac{1}{2}{ }^{\prime \prime}$ needles and a $60 \mathrm{~mL}$ syringe. We placed blood in sterile, $10-\mathrm{mL}$, serum tubes and centrifuged the blood within $4 \mathrm{~h}$ of collection. We stored serum in cryovials $(2-5 \mathrm{~mL})$ in a freezer $(-60 \mathrm{C})$ within 1-8 h. At the completion of captures each winter, serum samples were shipped overnight with ice packs to the Wyoming State Veterinary Laboratory (WSVL; Laramie, WY, USA). We also collected about 5-10 fecal pellets from the rectum of the animal using a gloved hand. We froze fecal samples and shipped them overnight with ice packs to the WSVL for pregnancy tests for all years and for parasites during 2001-02 (Baermann's test and eggs and oocysts). During 2001-02 we also collected one nasal swab sample from each elk using either the Baxter Healthcare Culturette System (Deerfield, Illinois, USA) or the Becton/Dickinson BBL CultureSwab (Sparks, Maryland, USA) for bacteria and virus isolations. Nasal samples were maintained at $5^{\circ} \mathrm{C}$ and shipped within $24 \mathrm{~h}$ to the WSVL for bacterial evaluation. Both the fecal and nasal swab tests were considered "gold standard" tests (Thrusfield, 2005) and actual disease-causing agents were detected. We also estimated age by tooth annuli (the fourth incisor during 2000 and the upper canine during 2001-02 and 2005), nutritional condition (during 2000-02) and pregnancy status (protein B specific for pregnancy via radioimmunoassay, BioTracking, Moscow, Idaho, USA) (Cook et al., 2004). Lactation and body fat data were collected during 2000-02 (Cook et al., 2004).

Whole-blood and serum were sent to WSVL for analyses. We tested sera for presence of antibodies (rather than the actual pathogen itself) against Anaplasma marginale, borderdisease virus, bovine-respiratory syncytial virus, bovine-virus-diarrhea virus type 1 and type 2, Brucella abortus, Chlamydophilia, epizootic-hemorrhagic-disease virus, infectious-bovine rhinotracheitis virus, Leptospira spp., parainfluenza-3 virus and Mycobacterium paratuberculosis during 2000-02, 2005 using tests indicated in Table 1. The WSVL summarized A. marginale, B. abortus, Chlamydophilia, epizootic-hemorrhagic-disease virus and M. paratuberculosis results as positive or negative (all evaluations were bovine-based except for B. abortus tests which were elk-validated and none of the tests were considered "gold standard" tests; Thrusfield, 2005). Leptospirosis exposure was evaluated at 1:100 dilution. Other disease titers were considered as follows: $>1: 16$, exposed to the disease; $=1: 16$, possibly exposed; and $<1: 16$, not exposed (except for parainfluenza-3 virus because these titers were not reported in 1:4 dilutions and, therefore, these titers were interpreted as follows: $>1: 20$, exposed; $=1: 20$, possibly exposed; and $<1: 20$, not exposed). After discussions with WSVL staff we set these conservative titer categories to avoid falsely identifying an animal as exposed to disease (see Goyal et al., 1988). We constructed 95\% confidence intervals for seroprevalence following Thursfield (2005). 
TABLE 1.-Disease seroprevalence tests performed on blood sampled from adult, female elk on Yellowstone's northern range during winter 2000-02 and 2005. Unless otherwise noted all tests were conducted at the Wyoming State Veterinary Lab (WSVL)

\begin{tabular}{|c|c|c|c|c|}
\hline Disease $^{a}$ & $\begin{array}{l}\text { Year(s) Sample (s) } \\
\text { Collected }\end{array}$ & $\begin{array}{l}\text { Year(s) Sample(s) } \\
\text { Analyzed }\end{array}$ & Test $^{b, c}$ & Comments \\
\hline ANA & 2000, 2002, 2005 & 2005 & ELISA & - \\
\hline BDV & 2001, 2002 & 2001, 2002 & SN & - \\
\hline \multirow[t]{2}{*}{ BRSV } & 2000,2005 & 2005 & SN & - \\
\hline & 2001, 2002 & 2001, 2002 & SN & - \\
\hline \multirow[t]{2}{*}{ BVD-1 } & 2000,2005 & 2005 & $\mathrm{SN}$ & - \\
\hline & 2001, 2002 & 2001, 2002 & SN & - \\
\hline BVD-2 & 2001, 2002 & 2001, 2002 & SN & - \\
\hline $\mathrm{BRU}$ & 2000-2002, 2005 & 2000-2002, 2005 & $\begin{array}{l}\text { CARD, SPT, } \\
\text { RIV }^{d}\end{array}$ & - \\
\hline \multirow[t]{2}{*}{ Chlamydophilia } & 2000 & 2000 & $\mathrm{SN}$ & $\begin{array}{l}\text { Tested at the Texas Veterinary } \\
\text { Medical Diagnostic } \\
\text { Laboratory System, } \\
\text { Amarillo, TX }\end{array}$ \\
\hline & 2001, 2002 & 2001, 2002 & $\mathrm{SN}$ & Tested at the WSVL \\
\hline EHDV & 2001, 2002 & 2001, 20002 & AGID & - \\
\hline \multirow[t]{2}{*}{ IBR } & 2000,2005 & 2005 & $\mathrm{SN}$ & - \\
\hline & 2002 & 2002 & SN & - \\
\hline \multirow[t]{2}{*}{ LEPTO } & 2000,2005 & 2005 & MAT & - \\
\hline & 2001, 2002 & 2001, 2002 & MAT & - \\
\hline PI-3 & 2000-2002, 2005 & 2000-2002, 2005 & SN & - \\
\hline \multirow[t]{2}{*}{ РТВ } & 2000,2005 & 2005 & ELISA & - \\
\hline & 2001, 2002 & 2001, 2002 & AGID & - \\
\hline
\end{tabular}

${ }^{a}$ ANA, Anaplasma marginale, BDV, border-disease virus; BRSV, bovine-respiratory syncytial virus; BVD1 and BVD-2, bovine-virus-diarrhea virus type 1 and 2; BRU, Brucella abortus; EHDV, epizootichemorrhagic-disease virus; IBR, infectious-bovine rhinotracheitis virus; LEPTO, Leptospirosis spp.; PI-3, parainfluenza-3 virus; PTB, Mycobacterium paratuberculosis

${ }^{b}$ ELISA, enzyme-linked immunosorbent assay; SN, serum neutralization; CARD, card test; STP, standard-plate test; RIV, rivanol-precipitation-aggultination; AGID, standard agar-gel immunodiffusion; MAT, microscopic agglutination test

${ }^{c}$ Tests for Brucella abortus were USDA/APHIS validated for elk. The other tests were bovine-validated

${ }^{d}$ Morton et al. 1981

Hematology was analyzed using the Idexx QBC VetAutoread (QBC Diagnostics Inc., State College, Pennsylvania, USA) and included hemoglobin, packed-cell volume, platelets, whiteblood-cell counts and differentials including segmented neutrophils, banded neutrophils, lymphocytes, monocytes, eosinophils and basophils (slides prepared at the WSVL), and mean corpuscular hemoglobin concentration. Samples from 2002 and 2005 were analyzed for serum concentrations of urea nitrogen, total protein, albumin, calcium, magnesium, inorganic phosphorus, alkaline phosphatase, creatine kinase, aspartate aminotransferase, gamma glutamyltransferase, lactate dehydrogenase, gamma globulins and glucose using the Idexx VetTest Chemistry Analyzer prior to 2003 (Idexx Laboratories Inc., Westbrook, Maine, USA) and the VetEx Autoanalyzer after 2003 (Alfa Wasserman, West Caldwell, New Jersey, USA). Total serum thyroxine was analyzed using the VetEx Autoanalyzer (Alfa Wasserman, West Caldwell, New Jersey, USA). Trace minerals including zinc, copper, iron, manganese and molybdenum from serum and selenium from blood were analyzed by 
inductively coupled plasma-mass spectrometry with the Elan 6100 (PerkinElmer, Norwak Connecticut, USA).

We compared disease seroprevalences and blood parameters during winters 2000-02, and 2005 with values reported for: (1) 143 male and female (unknown sex ratio) elk $>$ 2-y old from northern Yellowstone that migrated outside the park and were harvested by hunters prior to wolf restoration (Aguirre et al., 1995); (2) 209 female elk $\geq 3$-y old (blood parameter comparisons) and 913 female and male elk (disease seroprevalence comparisons) of western Montana captured in the Gravelly-Snowcrest Mountains of Montana by helicopter net driving, drug immobilization, darting from a helicopter and a hand-held net gun fired from a helicopter during 1984-1996 (Hamlin and Ross, 2002); (3) 28 adult-female elk captured from the Garnet Mountains in west-central Montana with ballistic nets fired from a helicopter during 2002-04 (2006; M. Thompson, Montana Fish, Wildlife, and Parks, pers. comm.); and (4) standards for captive female elk $>2$-y old reported by the International Species Information System from 19 member institutions (ISIS, 2002).

We used two factorial analysis of variance (ANOVA) models to assess relationships between disease seroprevalence or parasite values for northern Yellowstone elk during 2000-05 and covariates including capture year, age (2-9 y old, and $\geq 10$-y old) and body fat $(<5 \%, 5-10 \%$ and $>10 \%$; during 2000-2002). One ANOVA model used all the available data for a particular disease or parasite value and capture year and age covariates and a 2nd model was limited in years by the addition of body-fat data.

We used factorial ANOVA to assess relationships between individual blood parameters for northern Yellowstone elk during 2000-2005 and covariates including capture year, pregnancy status, age (2-9 y old and $\geq 10$-y old), body fat $(<5 \%, 5-10 \%$ and $>10 \%)$, and lactation status. We converted all continuous variables to logarithm base 10 to stabilize variance and lessen the impact of extremes for ANOVA analyses. We first added 0.5 to each monocyte, banded neutrophil, and eosinophil value because these covariates included numerous zero values (Krebs, 1999). We obtained geometric means by back-transforming the logarithms and created three factorial ANOVA models for each blood parameter. One model used all the available data, while a 2nd model was temporally limited to 2000-02 data by the inclusion of body-fat data and a 3rd model was similarly limited by the inclusion of lactation data. Only 2-way interactions were assessed among covariates due to sample-size limitations. We performed all analyses using Statistica v.6 (StatSoft, Tulsa, Oklahoma, USA) and considered differences significant at $\alpha \leq 0.05$.

\section{RESULTS}

We captured and sampled 115 adult female elk on the northern range of Yellowstone during winters 2000-02 and 2005. Seroprevalences and 95\% confidence intervals follow: bovine-virus-diarrhea virus type 1, 24\% (16-32\%); bovine-virus-diarrhea type 2, $6 \%(0-12 \%)$, infectious-bovine rhinotracheitis virus, $4 \%$ (0-8\%); parainfluenza-3 virus, $70 \%(61-79 \%)$; bovine-respiratory syncytial virus, $0 \%$; Brucella abortus, 2\% (0-5\%); Leptospira spp., 17\% (1023\%); Anaplasma marginale, 29\% (18-39\%); Mycobacterium paratuberculosis, 0\%; and epizootic hemorrhagic virus, $0 \%$ (Table 2). Presence of nasal bacteria (e.g., Enterobacter, Streptomyces) was low $(4 \%, 95 \% \mathrm{CI}=0-9 \%)$, and parasites were detected in $31 \%(95 \% \mathrm{CI}=18-45 \%)$ of fecal samples using Baermann's test and in $57 \%(95 \% \mathrm{CI}=42-71 \%)$ of samples examined for eggs and oocysts (Table 3). No disease or parasite value was related to age or body fat (Table 4).

Disease seroprevalences for northern Yellowstone elk 5-10 y after wolf restoration [post$\mathrm{WR}$ ] compared to those prior to wolf restoration [pre-WR] were substantially lower for bovine-virus-diarrhea virus type 1 [95\% CI pre-WR $=73.1-86.3$, post-WR $=15.9-31.9]$ and 


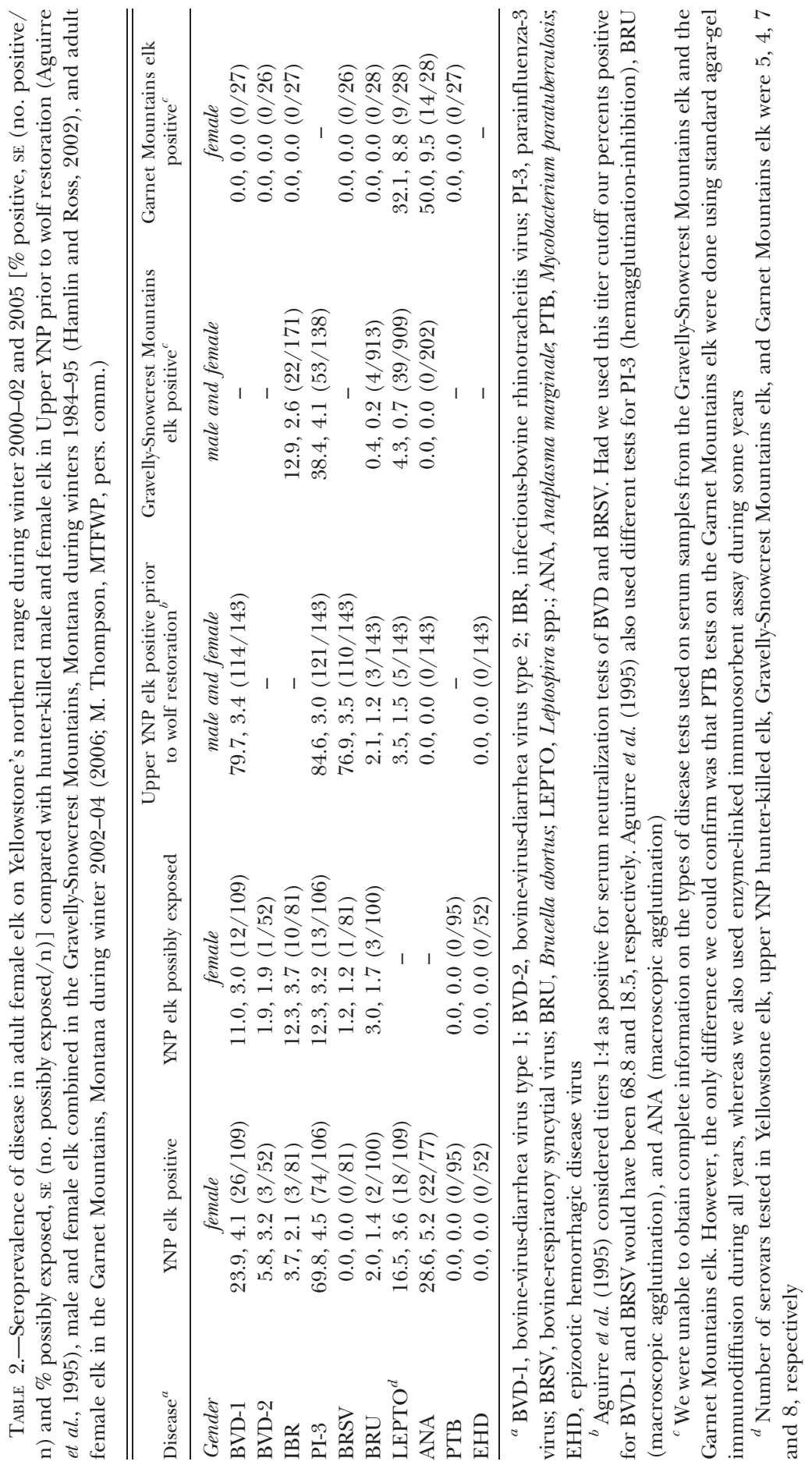


TABLE 3.-Other disease, bacteria, parasite, and virus profiles [\% positive, $\mathrm{SE}$ (no. positive/n) and $\%$ possibly exposed, SE (no. possibly exposed/n)] evaluated in Yellowstone's northern-range, adult female elk during winters 2000-02 and 2005

\begin{tabular}{|c|c|c|c|}
\hline Pathogen & $\begin{array}{l}\text { YNP elk } \\
\text { positive }\end{array}$ & $\begin{array}{l}\text { YNP elk possibly } \\
\text { exposed }\end{array}$ & Comments \\
\hline Border disease virus & $7.8,3.8(4 / 51)$ & $13.7,4.8(7 / 51)$ & - \\
\hline Chlamydophilia & $0.0,0.0(0 / 96)$ & $9.4,3.0(9 / 96)$ & - \\
\hline Bacteria (nasal swab) & $4.0,2.8(2 / 50)$ & - & $\begin{array}{l}1 \text { Enterobacter and } 1 \text { Streptomyces } \\
\text { detection }\end{array}$ \\
\hline Viruses (nasal swab) & $0.0,0.0(0 / 52)$ & - & - \\
\hline \multicolumn{4}{|l|}{ Parasites (fecal) } \\
\hline Baermann's test & $31.1,6.9(14 / 45)$ & - & $\begin{array}{l}\text { Mean lungworm larvae } / \mathrm{gm}=1.43 ; 0.88 \\
\text { SD; range 0-3.46 }\end{array}$ \\
\hline Eggs \& oocysts & $56.5,7.3(26 / 46)$ & - & $\begin{array}{l}\text { Various Eimeria (also non-pathogenic), } \\
\text { small Trichostrongylids, Moniezia, } \\
\text { Trichuris, and mites detected }\end{array}$ \\
\hline
\end{tabular}

bovine-respiratory syncytial virus $[95 \%$ CI pre-WR $=70.0-83.8$, post-WR $=0]$ ) while similar (e.g., Brucella abortus [95\% CI pre-WR $=0-4.45$, post-WR $=0-4.74]$ and epizootic hemorrhagic disease virus $[95 \%$ CI pre-WR $=0$, post-WR $=0]$ ) or higher for others $(e . g$., Anaplasma marginale [95\% CI pre-WR $=0$, post-WR $=18.5-38.7$ ] and Leptospira spp. [95\% CI pre-WR $=0.5-6.5$, post-WR $=9.5-23.5]$ ) (Table 2). Compared to other Montana elk herds (Garnet Mountains [GM] and Gravelly-Snowcrest [GS]) 95\% confidence intervals for disease seroprevalences of northern Yellowstone elk following wolf restoration were higher for parainfluenza-3 virus (95\% CI YNP $=61.1-78.6$, GS $=30.3-46.5)$ and bovine-virusdiarrhea virus type $1(95 \% \mathrm{CI} \mathrm{YNP}=15.9-31.9, \mathrm{GM}=0)$ (Table 2$)$.

Pregnant elk had lower monocytes $\left(\mathrm{P}=0.05, \mathrm{~F}_{1,42}=4.20\right)$ and higher albumin, calcium, gamma globulins, magnesium, and protein (all $\mathrm{P} \leq 0.04, \mathrm{~F}_{1,28} \geq 4.71$ ). No blood values were related to lactation or body fat after accounting for capture year, age and pregnancy, except for segmented neutrophils which varied by the interaction between age and body fat $\left(\mathrm{P}=0.02, \mathrm{~F}_{2,35}=4.57\right)($ Tables 5, 6).

\section{DisCUSSION}

The values for selected blood parameters for northern Yellowstone elk during 2000-02 and 2005 were generally similar to those from the Gravelly-Snowcrest and Garnet Mountains

TABLE 4.-Reproductive and condition characteristics (mean, sE, n) [min, max] of adult, female elk on Yellowstone's northern range during winters 2000-2002 and 2005

\begin{tabular}{lcccr}
\hline \hline Year & Age (yr) & $\begin{array}{c}\text { Proportion } \\
\text { Pregnant }\end{array}$ & $\begin{array}{c}\text { Proportion Currently } \\
\text { Lactating }\end{array}$ & \multicolumn{1}{c}{$\%$ Fat } \\
\hline $2000^{a}$ & $7.56(0.60,42)[1,15]$ & $0.84(0.06,43)$ & - & $8.85(0.50,40)[1.79,14.32]$ \\
$2001^{a}$ & $11.12(0.80,28)[4,18]$ & $0.78(0.08,28)$ & $0.09(0.06,23)$ & $9.78(0.80,28)[1.80,16.55]$ \\
$2002^{a}$ & $8.75(0.79,24)[1,15]$ & $0.83(0.08,23)$ & $0.17(0.08,24)$ & $10.14(0.75,24)[2.94,15.03]$ \\
2005 & $8.32(0.79,17)[2.5,16]$ & $0.94(0.06,17)$ & - & - \\
\hline
\end{tabular}

${ }^{a}$ Means for 2000-2002 were also reported by Cook et al. 2004. The differences in reported mean ages are due to interpretation of values such as " $10+$ " from teeth annuli. For our analysis, we disregarded any " +" associated with estimated age 
TABLE 5.-Blood parameters of adult, female elk on Yellowstone's northern range during winters 2000-2002 and 2005 compared to age, pregnancy, lactation and body fat

\begin{tabular}{|c|c|c|c|}
\hline Blood characteristic & Elk characteristic & $\mathrm{P}$ & Means $(95 \%$ CI, n) \\
\hline $\begin{array}{l}\text { Segmented neutrophils } \\
\quad(\%)\end{array}$ & age $\times$ body fat & 0.02 & $\begin{array}{l}\text { age } 2-9 \text {; body fat }<5 \%=46.48(36.24-59.61,3), \\
\text { age } 2-9 \text {; body fat } 5-10 \%=22.36(12.92-38.72,8), \\
\text { age } 2-9 \text {; body fat }>10 \%=23.15(17.30-30.99,15), \\
\text { age } 10+\text {; body fat }<5 \%=26.84(13.17-54.66,5), \\
\text { age } 10+\text {; body fat } 5-10 \%=41.19(30.53-55.57,6), \\
\text { age } 10+\text {; body fat }>10 \%=34.62(29.82-40.20,14)\end{array}$ \\
\hline
\end{tabular}

herds, with some notable exceptions. Northern Yellowstone elk had lower mean serum urea nitrogen than elk from the Gravelly Snowcrest Mountains, the Garnet Mountains and ISIS standards. Serum urea nitrogen (SUN) is an indicator of protein quality in the diet and has been related to nutritional condition in white-tailed deer (DelGiudice et al., 1987). Renal disease and hydration status can also impact SUN (Coles, 1980; DelGiudice et al., 1987). Isolated interpretation of SUN is not possible as moderately high levels may indicate increasing levels of dietary protein intake (Cook, 2002), while diets with very high energy intake may have very low levels of serum urea nitrogen due to the rumen microbes more efficiently utilizing the proteins and thus, producing less urea (Harder and Kirkpatrick, 1994). Northern Yellowstone elk also had reduced lymphocytes compared to elk from the Garnet Mountains. Lymphocytes are white blood cells important in cell-mediated (T-cells) and humoral (B-cells) immune responses and both increases and decreases in lymphocytes can be signs of disease (Tizard, 1992). Thus, this finding alone cannot be interpreted to indicate either herd was in better overall condition.

Northern Yellowstone elk had higher seroprevalences of parainfluenza-3 virus, bovine-virusdiarrhea virus types 1 and 2 and brucellosis compared to those from the Gravelly-Snowcrest and Garnet Mountains herds. With greater wolf densities in northern Yellowstone, elk herd dynamics following wolf restoration may actually increase disease transmission depending on the specific epidemiology of these diseases. During winter northern Yellowstone elk were found in larger groups following wolf restoration (Mao, 2003), possibly because this may reduce predation risk via the dilution effect (Hamilton, 1971) and allow elk to more easily detect wolves through increased vigilance (Pulliam, 1973). However, aerial survey data from more recent research indicates that at least in some areas elk are found in smaller groups following wolf restoration (P. J. White, National Park Service, unpubl. data). Because elk grouping following wolf restoration is not fully understood, we cannot reliably attribute increased disease seroprevalence to increased elk herding.

Disease seroprevalences for northern Yellowstone elk were substantially lower 5-10 y following wolf restoration for bovine-virus-diarrhea virus type 1 and bovine-respiratory syncytial virus, but similar for Brucella abortus and epizootic hemorrhagic disease while higher for Anaplasma marginale and Leptospira spp. Determining whether wolves (through direct impacts via predation and/or indirect impacts through elk behavioral changes) caused these changes in elk disease seroprevalence would require substantially more knowledge of the epidemiology of each disease. Because only limited information is available about disease transmission dynamics and clinical manifestations in wild elk only plausible inferences are possible and causation cannot be determined.

For examples, parainfluenza-3 viruses cause mild respiratory disorders in domestic cattle and sheep that serve as initiators for secondary infections of Pasteurella spp., which can result 


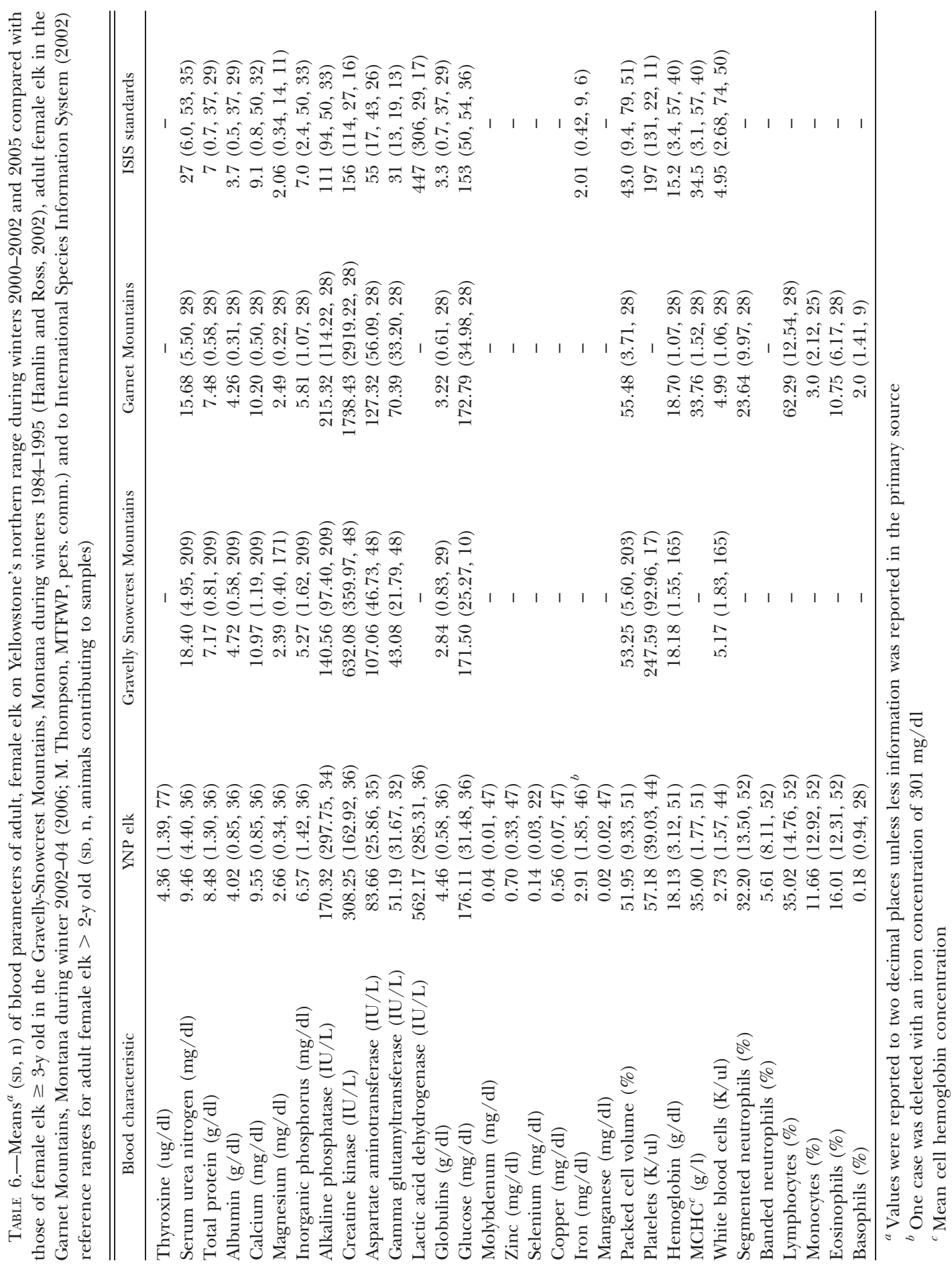


in bacterial pneumonia (Martin, 1996; Storz et al., 2000). Whether this virus causes clinical symptoms in wild elk remains unknown. However, if elk exhibit respiratory difficulties, it is easy to imagine them being predisposed to wolf predation during a chase. Bovine-virusdiarrhea virus causes enteritis, mucosal disease, infections, and respiratory and reproductive disorders in cattle (Baker, 1995), though experimentally inoculated non-pregnant elk showed no clinical signs and remained healthy for $>50 \mathrm{~d}$ post inoculation (Tessaro et al., 1999). Therefore, if the lack of clinical signs in non-pregnant elk is similar in wild elk (including those pregnant) then it appears unlikely that elk infected with this virus would face increased vulnerability to wolf predation. Regarding anaplasmosis, significant clinical disease in elk has not been reported (mild anemia followed by recovery has been observed; Smits, 1991), although in cattle the disease can cause anemia, jaundice, and possibly death (Thorne et al., 2002). While clinical signs of leptospirosis have been detected in captive red deer, only serologic evidence of infection has been reported in elk (Thorne et al., 2002). Clinical signs other than death may include bloody urine and kidney disease, hemolysis and jaundice, and depression (Thorne et al., 2002). If wild elk infected with Leptospira spp. exhibit clinical signs similar to captive red deer, it is conceivable that they may be vulnerable to increased predation by wolves. In contrast, epizootic hemorrhagic disease produced only mild fever in clinical trials of infected wapiti (Smits, 1991), which likely would not increase vulnerability of prey to wolf predation. Elk infected with Mycobacterium paratuberculosis may show non-specific clinical signs including poor weight gain and poor shedding of hair coat and just prior to death rapid weight loss and diarrhea may occur (Smits, 1991). Given these clinical manifestations, elk with paratuberculosis may be more vulnerable to wolf predation.

Similarly, it is possible that wolves may select for elk with brucellosis infections, at least in chronic cases, because these cases may cause bursitis, synovitis, and arthritis resulting in lameness (Thorne et al., 1978; Herriges et al., 1989). However, it is unclear whether this selection would result in a detectable decrease of seroprevalence because elk without chronic cases do not exhibit these symptoms. Also, elk interactions with bison in Yellowstone are important because Yellowstone bison have 50-60\% seroprevalences of brucellosis (Ferrari and Garrott, 2002). Our results suggest the seroprevalence of brucellosis has not appreciably increased in Yellowstone elk during the past decade. Seroprevalence during 2000-2005 was $2 \%(95 \% \mathrm{CI}=0-4.74)$ compared to $1 \%(95 \% \mathrm{CI}=0-1 \%)$ in hunterkilled elk of both sexes sampled during 1991-1995 from 3 areas of Wyoming and Montana adjacent to the park (Rhyan et al., 1997) and 3\% (95\% CI $=0-6 \%)$ in central Yellowstone adult female elk during 1996-1998 (Ferrari and Garrott, 2002). These seroprevalences are much lower than those documented among elk that used feedgrounds at the National Elk Refuge in Wyoming using similar tests to detect antibodies against Brucella abortus (25\%, 95\% CI $=20-31$ as cited in Table 1 of Ferrari and Garrott, 2002).

Thirty-one percent of northern Yellowstone elk tested positive for lungworm compared to 9-43\% during the 1960s (Barrett and Worley, 1966; Greer, 1968) and <20\% during 19891995 (Foos, 1997; Rhyan et al., 1997). Parasite load can affect vulnerability to predation and intraspecific competition (Mech, 1966; Davies, 1978; Anderson, 1979; Holmes, 1982). The prevalence of lungworm infection during 2000-2005 was not remarkably high (31\%, 95\% CI $=18-45 \%)$ and the mean larvae/gm $(1.43 ; 0.88 \mathrm{sD})$ was moderate (Table 3$)$. However, the relatively low intensity of infection could increase in future years given the current prevalence of approximately $31 \%$.

Five-10 y after wolf restoration, disease seroprevalences for northern Yellowstone elk were substantially lower for bovine-virus-diarrhea virus type 1 and bovine-respiratory syncytial virus, but similar for Brucella abortus and higher for Anaplasma marginale and Leptospira spp. 
Thus, our prediction that selective predation by wolves would reduce disease prevalence was only partly supported. For some diseases (e.g., anaplasmosis, bovine-viral-diarrhea, leptospirosis and epizootic hemorrhagic disease) wild elk may not exhibit clinical symptoms that would increase their vulnerability to wolf predation or they may only show clinical signs years after infection (e.g., bovine tuberculosis, Thorne et al., 2002). If we assume that a particular disease leads to deficiencies that are exploitable by wolves, we may expect disease prevalence to decrease as a result of wolf selective predation. However, as discussed above, diseases may potentially be more readily transmitted between elk following wolf restoration if elk grouping behaviors are significant to a particular disease's dynamics. Depending on the transmission dynamics of A. marginale and Leptospira spp. in wild elk, this may explain why we observed higher prevalences in elk following wolf restoration.

Further complications in interpreting our results arise because of the limited specificity (proportion of true negatives that are detected) and sensitivity (proportion of true positives that are detected) of the disease tests themselves (in part because most of the tests we used were bovine-validated and not "gold standards") (Thrusfield, 2005). Some of the difference in comparisons between pre- and post-wolf seroprevalences may potentially be attributed to different tests and methods such as titer level interpretation (see Table 2). Additionally, our comparisons were hampered by limited overlap in the pathogens surveyed. Nevertheless, the fact that post-wolf seroprevalence for some diseases were so much lower suggests that wolves could be selecting individuals with those diseases and reducing their prevalence or reducing the overall herd sufficiently to reduce the transmission of this disease and therefore, the prevalence. Certainly this finding could form a valuable hypothesis for other studies to test.

This was the first detailed assessment of disease seroprevalences and blood profiles of elk in Yellowstone and, as a result, there were only sparse data available for comparison. Our reference values will facilitate more rigorous future evaluations of potential predator "sanitation" effects, especially when the epidemiology of these diseases in wild prey is more fully understood.

Acknowledgments.-This study was financed by the Biological Resources Discipline of the United States Geological Survey; National Geographic Society; National Park Service; National Science Foundation grant 078130 to P. Turchin, J. Fryxell, M. Turner, M. Boyce and E. Merrill; and the Natural Sciences and Engineering Research Council of Canada. The following individuals assisted with capture, data collection, and/or administration of the project: M. Boyce, S. Chin, T. Clark, T. Davis, S. Evans, D. Guernsey, Hawkins and Powers Aviation, D. Ireland, D. Kirchhof, Leading Edge Aviation, J. Mao, W. Maples, Montana Aircraft, R. Peterson, D. Smith, D. Stahler, L. Thurston, J. Treanor, N. Varley, G. Wright and T. Wyman. H. Edwards, K. Bardsley and others with the Wyoming State Veterinary Lab provided background information regarding tests used to screen for diseases and blood profiles. Previous drafts of this manuscript were greatly improved by comments from A. Breed, G. DelGiudice, T. Kreeger and M. Nelson. We thank A. Breed for providing the algorithm we used to determine confidence intervals for seroprevalence data.

\section{Literature Cited}

Animal Care and Use Committee. 1998. Guidelines for the capture, handling, and care of mammals as approved by the American Society of Mammalogists. J. Mammal., 79:1416-1431.

Aguirre, A. A., D. E. Hansen, E. E. Starkey and R. G. McLean. 1995. Serologic survey of wild cervids for potential disease agents in selected national parks in the United States. Prev. Vet. Med., 21:313-322.

Anderson, R. C. 1979. The influence of parasitic infection on the dynamics of host population growth, p. 245-281. In: R. M. Anderson, B. D. Turner and L. R. Taylor (eds.). Population dynamics. Blackwell, Oxford, England. 
BAKer, J. C. 1995. The clinical manifestations of bovine viral diarrhea infection. Veterinary Clinics of North America: Food Animal Practice, 11:627-640.

Barber, S. M., L. D. Mech And P. J. White. 2005. Yellowstone elk calf mortality following wolf restorationbears remain top summer predators. Yellowstone Science, 13:37-44.

Barrett, R. E. AND D. E. Worley. 1966. The incidence of Dictyocaulus spp. in three populations of elk in south-central Montana. Bull. of the Wildl. Dis. Assoc., 2:5-6.

Coles, E. H. 1980. Veterinary clinical pathology. W. B. Saunders Co., Philadelphia, Pennsylvania. 562 p.

Cook, J. G. 2002. Nutrition and food, p. 259-349. In: D. E. Toweill and J. W. Thomas (eds.). North American elk ecology and management. Smithsonian Institution Press, Washington and London.

Cook, R. C., J. G. Cook And L. D. Месн. 2004. Nutritional condition of northern Yellowstone elk. J. Mammal., 85:714-722.

Davies, N. B. 1978. Ecological questions about territorial behaviour, p. 317-350. In: J. R. Krebs and N. B. Davies (eds.). Behavioural ecology: an evolutionary approach. Blackwell, Oxford, England.

Delgiudice, G. D., L. D. Mech, U. S. Seal and P. D. Karns. 1987. Effects of winter fasting and refeeding on white-tailed deer blood profiles. J. Wildl. Manag., 51:865-873.

Depner, K., O. J. B. Hubschle and B. Liess. 1991. Prevalence of ruminant pestivrius infections in Namibia. Ondersterpoort J. Vet. Res., 58:107-109.

Evans, S. B., L. D. Mech, D. W. Smith, P. J. White and G. A. Sargeant. 2006. Survival and causes of mortality of cow elk in Yellowstone's northern range. J. Wildl. Manag., 70:1372-1378.

Ferrari, M. J. and R. A. Garrott. 2002. Bison and elk: brucellosis seroprevalence on a shared winter range. J. Wildl. Manag., 66:1246-1254.

Foos, M. K. 1997. Pilobolus and lungworm disease affecting elk in Yellowstone National Park. Myco. Res., 101:1535-1536.

Frolich, K. 2000. Viral diseases of northern ungulates. Rangifer, 20:83-97.

Fuller, W. A. 1966. The biology and management of bison of Wood Buffalo National Park. Can. Wildl. Serv., Wildl. Mgmt. Bull. Ser. 1, No. 16.

Greer, K. R. 1968. Special collections-Yellowstone elk study, 1967-68. Montana Fish and Game Department Report W-83-R-11, Helena, Montana.

Goyal, S. M., M. A. Khan, S. W. McPherson, R. A. Robinson and W. J. Boylan. 1988. Prevalence of antibodies to seven viruses in a flock of ewes in Minnesota. Am. J. Vet. Res., 49:464-467.

Hamlin, K. L. And M. S. Ross. 2002. Effects of Hunting Regulation Changes on Elk and Hunters in the Gravelly-Snowcrest Mountains. Federal Aid Project W-120-R-Apr. 2002, Montana. Montana Fish, Wildlife and Parks, Wildlife Division, Helena, Montana.

Hamilton, W. D. 1971. Geometry for the selfish herd. J. Theor. Biol., 31:295-311.

Herriges, J. D., E. T. Thorne, S. L. Anderson and H. A. Dawson. 1989. Vaccination of elk in Wyoming with reduced dose strain 19 Brucella: controlled studies and ballistic field trials, p. 640-655. In: Proceedings of the 93rd Annual Meeting of the United States Animal Health Association. Las Vegas, Nevada.

Holmes, J. C. 1982. Impact of infectious disease agents on the population growth and geographical distribution of animals, p. 35-51. In: R. M. Anderson and R. M. May (eds.). Population biology of infectious disease. Springer-Verlag, New York, New York.

ISIS. 2002. Cervus elaphus, Red Deer, Females over 2 y. ISIS (International Species Information System), Apple Valley, MN, USA. Available at http://www.isis.org/ [accessed 17 Jan. 2006].

Krebs, C. J. 1999. Ecological Methodology, 2nd Edition. Addison Wesley Longman, Inc., Menlo Park, California. 620 p.

Lemke, T. O., J. A. Mack and D. B. Houston. 1998. Winter range expansion by the northern Yellowstone elk herd. Intermountain Journal of Sciences, 4:1-9.

MAO, J. S. 2003. Habitat selection by elk before and after wolf reintroduction in Yellowstone National Park, Wyoming. Thesis, University of Alberta, Edmonton, Canada.

Martin, W. B. 1996. Respiratory infections of sheep. Comp. Imm., Micro., and Infec. Dis., 19:171-179.

Mech, L. D. 1966. The wolves of Isle Royale. U.S. Nat. Park Serv. Fauna Ser. No. 7. 
1970. The wolf: the ecology and behavior of an endangered species. Doubleday Publishing Co., New York. 384 p.

—, L. G. Adams, T. J. Meier, J. W. Burch and B. W. Dale. 1998. The wolves of Denali. University of Minnesota Press, Minneapolis, Minnesota. 227 p.

— and R. O. Peterson. 2003. Wolf-prey relations, p. 131-157. In: L. D. Mech and L. Boitani (eds.). Wolves: behavior, ecology, and conservation. University of Chicago Press, Chicago, Illinois.

Murie, A. 1944. The wolves of Mount McKinley. U.S. Nat. Park Serv. Fauna Ser. No. 5.

NRC. 2002. Chapter 5: conclusions and recommendations, p. 120-137. In: Ecological dynamics on Yellowstone's Northern Range: the report of the National Academy of Sciences. NRC (National Research Council), National Academy Press, Washington, D.C.

Pulliam, H. R. 1973. On the advantages of flocking. J. Theor. Biol., 38:419-422.

Rhyan, J. C., K. Aune, D. R. Ewalt, J. Marquardt, J. W. Mertins, J. B. Payeur, D. A. Saari, P. Schladweiler, E. J. Sheehan and D. WorLey. 1997. Survey of free-ranging elk from Wyoming and Montana for selected pathogens. J. Wildl. Dis., 33:290-298.

Smith, D. W., T. D. Drummer, K. M. Murphy, D. S. Guernsey and S. B. Evans. 2004. Winter prey selection and estimation of wolf kill rates in Yellowstone National Park, 1995-2000. J. Wildl. Manag., 68:153-166.

, R. O. Peterson and D. B. Houston. 2003. Yellowstone after wolves. BioSci., 53:330-340.

Smits, J. E. G. 1991. A brief review of infectious and parasitic diseases of wapiti, with emphasis on western Canada and the northwestern United States. Can. Vet. J., 32:471-479.

Storz, J., X. Lin, C. W. Purdy, V. N. Chouljenko, K. G. Kousoulas, F. M. Enright, W. C. Gilmore, R. E. Briggs AND R. W. LoAn. 2000. Coronavirus and Pasteurella infections in bovine shipping fever pneumonia and Evan's Criteria for Causation. J. Clin. Micro., 38:3291-3298.

Tessaro, S. V., P. S. Carman and D. Deregt. 1999. Viremia and virus shedding in elk infected with Type 1 and virulent Type 2 bovine viral diarrhea virus. J. Wildl. Dis., 35:671-677.

Thrusfield, M. 2005. Veterinary epidemiology, 3rd edition. Blackwell Science, Oxford, UK. 584 p.

TizArd, I. 1992. Veterinary immunology: an introduction. W.B. Saunders Company, Philadelphia, Pennsylvania. 498 p.

Thorne, E. T., J. K. Morton, F. M. Blunt and H. A. Dawson. 1978. Brucellosis in elk. II. Clinical effects and means of transmission as determined through artificial infections. J. Wildl. Dis., 14:280-291.

— - E. S. Williams, W. M. Samuel and T. P. Kistner. 2002. Diseases and parasites, p. 351-387. In: D. E. Toweill and J. W. Thomas (eds.). North American Elk: Ecology and Management. Smithsonian Institution Press, Washington, D.C.

USDOI AND USDA. 2000. Record of decision for the Interagency Bison Management Plan for the state of Montana and Yellowstone National Park. USDOI and USDA (U.S. Department of the Interior and U.S. Department of Agriculture), Washington, D.C.

White, P. J. and R. A. Garrott. 2005. Northern Yellowstone elk after wolf restoration. Wildl. Soc. Bull., 33:942-955.

Wolfe, M. L., J. F. Kimball, Jr. and G. T. M. Schildwatcher. 2002. Refuges and elk management, p. 583-616. In: D. E. Toweill and J. W. Thomas (eds.). North American Elk: Ecology and Management. Smithsonian Institution Press, Washington, D.C. 